\title{
IMPLEMENTASI PENILAIAN OTENTIK BIDANG STUDI PENDIDIKAN AGAMA ISLAM DAN BUDI PEKERTI DI SMAN 1 DEMPET JAWA TENGAH
}

\author{
Hadi Nurrohim \\ Universitas Islam Sultan Agung Semarang \\ hadinurrohim@gmail.com
}

\begin{abstract}
Authentic assessment is a variant of assessment in the Curriculum 2013. Authentic assessment needs to be implemented well in every field of study, so that learners can get maximum results. Public senior high school 1 Dempet is one of the schools that has implemented the Curriculum 2013, as well as its authenticassessment which is special in the field of study of Islamic Education and Character. This authentic assessment can be successful if the teacher follows the procedures and steps. So also with the teachers of Islamic education in Public senior high school 1 Dempet, who with all the shortcomings and advantages apply authentic assessment. This study aims to identify and explain the process of choosing a strategy and establishing an approach in the authentic assessment of the field of Islamic education and Character Public senior high school 1 Dempet study. Then he explains and explains the strategies and approaches in the authentic assessment of Islamic education and Character Public senior high school 1 Dempet study areas. Two things are worth to investigate, given that there are still teachers who have not really understand and apply authentic assessment. Through this research, it is generated that Islamic education teachers have applied authentic assessments well, so that it can provide a positive for the learners.
\end{abstract}

Keywords: Authentic Assessment, Islamic Religious Education, Character

\begin{abstract}
Abstrak
Penilaian otentik merupakan varian penilaian yang ada di Kurikulum 2013. Penilaian otentik perlu diimplementasikan dengan baik dalam setiap bidang studi, agar para peserta didik bisa mendapatkan hasil yang maksimal. SMAN 1 Dempet adalah salah satu seklolah yang telah menerapkan Kurikulum 2013, sekaligus penilaian otentiknya yang khusus pada bidang studi Pendidikan Agama Islam dan Budi Pekerti. Penilaian otentik ini bisa berhasil jika guru mengikuti prosedur dan langkah-langkahnya.Begitu juga dengan guru-guru PAI di SMAN 1 Dempet, yang dengan segala kekurangan dan kelebihan menerapkan penilaian otentik. Penelitian ini bertujuan untuk mengetahui dan menjelaskan mengenai proses memilih strategi dan menetapkan pendekatan dalam penilaian otentik bidang studi PAI dan Budi Pekerti SMAN 1 Dempet. Kemudian mengatahui dan menjelaskan langkah-langkah strategi dan pendekatan dalam penilaian otentik bidang studi PAI dan Budi Pekerti SMAN 1 Dempet. Dua hal tersebut patut untuk diteliti, mengingat saat ini masih ada guru-guru yang belum begitu memahami dan menerapkan penilaian otentik.Melalui penelitian ini,
\end{abstract}


dihasilkan bahwa guru-guru PAI telah menerapkan penilaian otentik dengan baik, sehingga bisa memberikan hal yang positif bagi para peserta didik.

Kata Kunci: Penilaian Otentik, PAI, Budi Pekerti.

\section{A. PENDAHULUAN}

Pendidikan secara umum dapat dirumuskan sebagai pemberian bimbingan, agar potensi peserta didik berkembang semaksimal mungkin dalam semua aspek kehidupan.Pendidikan juga bisa dikatakan sebagai usaha sadar yang terencana dan sistemik. Pelaksanaan pendidikan selalu bersumber dari sejumlah landasan yang relevan dengan situasi dan kondisi saat ini Landasan dan asas tersebut sangat penting, karena landasan tersebut merupakan salah satu pilar utama dalam pelaksanaan pendidikan dan pengembangan manusia.

Pendidikan merupakan kebutuhan sepanjang hayat, setiap manusia membutuhkan pendidikan, sampai kapan dan di manapun ia berada. Pendidikan memiliki arti yang sangat penting, karena tanpa pendidikan manusia akan sulit berkembang bahkan terbelakang. Dengan demikian, pendidikan harus betul-betul diarahkan untuk menghasilkan manusia berkualitas dan mampu bersaing, di samping memiliki budi pekerti yang luhur dan moral yang baik.Pendidikan yang bisa menghasilkan manusia memiliki intelektual dan berbudi pekerti luhur ialah pendidikan yang selalu menghadirkan agama Islam. Pembelajaran agama Islam dapat memberikan pressing kepada para peserta didik untuk menyeimbangkan berbagai disiplin ilmu dengan agama Islam.

Dalam pembelajaran pendidikan agama Islam, peserta didik dapat menumbuhkan sikap aktif, kreatif dan inovatif, namun fakta yang terjadi ialah bahwa untuk menghasilkan peserta didik yang bersikap kreatif, tidaklah mudah dilaksanakan. Hal tersebut terjadi karena paradigma pembelajaran masih belum berubah, misalkan guru dianggap sumber belajar, proses pembelajaran yang terjadi memposisikan peserta didik sebagai pendengar ceramah guru, akibatnya proses belajar mengajar cenderung membosankan dan menjadikan peserta didik yang malas belajar, sikap peserta didik yang pasif tersebut ternyata tidak hanya terjadi pada bidang studi tertentu saja, tetapi hampir semua pelajaran termasuk Pendidikan Agama Islam.

Pada pengajaran pendidikan agama Islam, peserta didik diharapkan benar-benar aktif, sehingga berdampak pada keaktifan, kreatif, dan inovasi peserta didik tentang apa yang akan dipelajari.Setiap konsep yang dijabarkan dalam pendidikan agama Islam akan mudah dipahami dan diingat oleh peserta didik bila disajikan melalui prosedur dan langkah-langkah yang tepat, jelas dan menarik. Keaktifan peserta didik dalam belajar merupakan salah satu kegiatan pembelajaran yang menekankan beberapa kegiatan. Tindakan atau aktivitas yang aktif bisa menggunakan metode atau pendekatan tertentu dalam pembelajaran pada hakikatnya merupakan cara yang teratur dan berfikir secara sempurna. Untuk mencapai suatu tujuan pengajaran dan memperoleh kemampuan dalam mengembangkan efektivitas belajar, maka seorang guru harus menetapkan pendekatan atau metode yang baik, sehingga bisa berperan dalam 
menentukan berhasil atau tidaknya pembelajaran yang diinginkan, dengan demikian lembaga pendidikan mempunyai tanggung jawab yang besar memberikan pengarahan dan bimbingan kepada guru.Lembaga pendidikan Islam diharapkan dapat membina dan menghasilkan sumber daya manusia Islami sehingga menghasilkan alumni yang bermutu dengan memiliki wawasan ilmu pengetahuan, skill dan teknologi dan punya bekal iman takwa sehingga dapat menguasai, mengembangkan dan mengaplikasikan dengan tetap dilandasi nilai-nilai agama, moral, dan akhlak mulia sesuai dengan norma aturan agama maupun pemerintah $^{1}$. Pembelajaran tersebut sangat dipengaruhi oleh kurikulum yang diterapkan selama ini, oleh karenanya, kurikulum pendidikan perlu dikembangan untuk menciptakan suasana pembelajaran yang berbeda. Pengembangan kurikulum 2013 merupakan langkah kelanjutan pengembangan kurikulum berbasis kompetensi yang telah dirintis pada tahun 2004 dan KTSP 2006 yang mencakup kompetensi sikap,pengetahuan dan keterampilan secara terpadu. Mengingat tagihan masa kini dan ke depan yang lebih kepada kecerdasan jamak sikap,kecakapan dan pengetahuan, maka perubahan dan pengembangan kurikulum 2013 dipandang sangat relevan untuk menjawab kebutuhan itu. Kurikulum 2013 menggunakan pendekatan saintifik dan penilaian otentik, sehingga dalam pembelajaran bisa lebih maksimal.

Penilaian otentik (authentic assesment) menurut Abdul Majid adalah proses

1 M. Ihsan Dacholfany, Inisiasi Strategi Manajemen Lembaga Pendidikan Islam Dalam Meningkatkan Mutu Sumber Daya Manusia Islami di Indonesia Dalam Menghadapi Era Globalisasi, Jurnal At-Tajdid, Volume. 1, No. 1 Januari-Juni 2017, h.1. pengumpulan berbagai data yang bisa memberikan gambaran perkembangan peserta didik. $^{2}$ Adapun Imas dan Berlin mendefinisikan bahwa penilaian otentik (authetic assesment) merupakan penilaian yang dilakukan secara komprehensif untuk menilai, mulai dari masukan (input), proses, dan keluaran (output) pembelajaran yang meliputi ramah sikap, pengetahuan, dan keterampilan. ${ }^{3}$ Adapun Kunandar mengemukakan bahwa penilaian otentik adalah kegiatan menilai peserta didik yang menekankan pada apa yang seharusnya dinilai, baik proses maupun hasil dengan bebagai instrumen penilaian yang disesuaikan dengan tuntunan kompetensi yang ada di dalam Standar Kompetensi (SK) Kompetensi Inti (KI) dan Kompetensi Dasar (KD). ${ }^{4}$

Penilaian otentik ini mutlak harus dilakukan sebagai manifestasi dari implementasi kurikulum 2013, namun, dalam kenyataannya guru masih mengalami kesulitan dalam menerapkan penilaian otentik, baik dalam membuat perencanaan penilaian otentik, pelaksanaan maupun pengolahan penilaian hasil belajar.Hal ini terjadi karena pada aspek sarana, di sekolah/madrasah belum tersedia sarana yang mendukung penuh penerapan penilaian otentik, selain itu, hal yang paling urgen dalam hal ini adalah pemilihan strategi yang belum relevan dalam penerapan penilaian otentik.

2 Abdul Majid, Penilaian Autentik Proses danDesain Belajar(Bandung: PT. Remaja Rosdakarya, 2015), h. 57.

${ }^{3}$ Imas Kurniasih \& Berlin Sani, Implementasi Kurikulum 2013 Konsep \& Penerapan(Surabaya: Kata Pena, 2014), h. 48.

${ }^{4}$ Kunandar, Penilaian Outentik (Penilaian Hasil Belajar Peserta Didik Bedasarkan Kurikulum 2013) Satu Pendekatan Praktis, Disertai Dengan Contoh (Jakarta: PT.Raja Grafindo Persada, 2014), h. 35-56. 
Penilaian otentik nampaknya belum begitu akrab dengan aktivitas penilaian guru, sehingga guru masih perlu untuk mendalami penilaian otentik sekaligus mempraktikkan dengan maksimal.Penerapan strategi dalam penilaian otentik perlu analisis yang mendalam, agar sesuai dengan karakteristik penilaian otentik.Strategi merupakan salah satu kunci keberhasilan penerapan penilaian otentik di lembaga pendidikan, sehingga hal ini masih memerlukan perhatian yang sangat intens, kemudian hal lain yang sangat berkaitan dengan stratagi ialah pendekatan penilaian otentik. Kunandar mengemukakan bahwa penilaian pada kurikulum 2013 menggunakan pendekatan penilaian acuan patokan dan ketuntasan belajar. Di dalam melaksanakan penilaian otentik setiap bidang studi, makamenggunakan berbagai pendekatan yang ideal, agar penilaian yang dilaksanakan mendapatkan predikat baik. ${ }^{5}$

Dalam hal ini, implementasi strategi dalam penilaian otentik dikhususkan pada bidang studi Pendidikan Agama Islam dan Budi Pekerti.Hal tersebut menarik untuk diteliti, pasalnya Pendidikan Agama Islam dan Budi Pekerti merupakan bidang studi dasar yang harus dipahami dan diamalkan oleh setiap peserta didik.Pemahaman original peserta didik hanya akan diketahui melalui penilalain yang otentik.Lembaga pendidikan yang telah menerapkan strategi dan pendekatan dalam penilaian otentik pada bidang studiPendidikan Agama Islam dan Budi Pekerti telah banyak yang berhasil, dan ada juga yang belum maksimal.

Salah satu lembaga pendidikan yang telah menerapkan ialah SMAN 1 Dempet. SMAN 1 Dempet merupakan salah satu sekolah negeri yang terletak di Desa Botosengon Kecamatan Dempet Kabupaten Demak, Provinsi Jawa Tengah. Sekolah ini telah menerapkan kurikulum 2013 secara menyeluruh, sehingga penerapan penilaian otentik pada bidang studi Pendidikan Agama Islam dan Budi Pekerti bisa dideskripsikan dan dianalisis kesesuaiannya dengan mendalam.

Adapun hal yang menjadi fokus artikel ini didasarkan pada ruang lingkup strategi dan pendekatan guru PAI dalam implementasi penilaian otentik bidang studi Pendidikan Agama Islam dan Budi Pekerti, kemudian berlanjut pada penerapan strategi dan pendekatan guru PAI dalam implementasi penilaian otentik bidang studi Pendidikan Agama Islam dan Budi Pekerti, yangmeliputi: (perencanaan penilaian otentik, pelaksanaanpenilaian otentik, penilaian otentik hasil belajar peserta didik).

Berdasarkan latar belakang yang telah penulis paparkan di atas, maka rumusan masalah dalam artikel ini ialah:

1. Bagaimana proses memilih strategi dan menetapkan pendekatan dalam penilaian otentik bidang studi PAI dan Budi Pekerti SMAN 1 Dempet Jawa Tengah ?

2. Bagaimana langkah-langkah strategi dan pendekatan dalam penilaian otentik bidang studi PAI dan Budi Pekerti SMAN 1 Dempet Jawa tengah?

\section{B. METODE PENELITIAN}

Jenis penelitian ini adalah "Penelitian lapangan (field research), yang mengharuskan peneliti terjun ke lapangan untuk memperoleh gambaran yang akurat serta obyektif'

5Ibid.,h. 44. 
mengenai data yang dibutuhkan. ${ }^{6}$ Penelitian lapangan ini bersifat kualitatif, yang menggambarkan hasil penelitian dalam bentuk narasi.Dengan memakai jenis penelitian ini, maka peneliti bisa mendapatkan data yang otentik terkait SMAN 1 Dempet dan mengenai implementasi strategi dan pendekatan dalam penilaian otentik pada pendidikan agama Islam.

Sumber data dalam penelitian ini adalah subyek dari mana data diperoleh. ${ }^{7}$ Data yang diambil dalam penelitian ini terdiri dari data primer dan data sekunder sebagai berikut: data primer adalah "Penelitian yang diperoleh secara langsung dari sumber asli, tanpa melalui media perantara", 8 dan Data sekunder adalah "Data yang telah tersusun dalam bentuk dokumen-dokumen yang diperoleh dari tangan kedua.

Pengumpulan data adalah hal yang sangat penting dala penelitian, pengumpulan data kualitatif berbeda dengan penelitian kuantitatif yang mana dalam penelitian kualitatif instrumen peneliti adalah peneliti itu sendiri hubungan kerja antara peneliti dengan kelompok peneliti dengan subyek peneliti hanya berlaku dalam pengumpulan data melalui teknik observasi partisipan, wawancara yang mendalam dengan informan atau subjek penelitian, pengumpulan dokumen dengan melakukan penelaahan terhadap berbagi referensi yang sesuai dengan fokus penelitian.

${ }^{6}$ SuharsimiArikunto,Prosedur Penelitian Suatu Pendekatan Praktik (Jakarta: Rineka Cipta, 2006), h. 32.

${ }^{7}$ Ibid, h. 114.

${ }^{8}$ Nur Indrianto dan Bambang Supomo, Metodologi Penelitian Bisnis Untuk Akuntansi Manajemen (Yogyakarta: BPFF, 1999), h.146.

\section{PEMBAHASAN}

1. Tinjauan Secara Geografis

Secara geografis, letak SMAN 1 Dempet berada di Desa Botosengon Kecamatan Dempet Kabupaten Demak, Provinsi Jawa Tengah dengan kode pos 59573. SMAN 1 Dempet terletak di Desa Botosengon berbatasan sebelah utara dengan Desa Kedungori, sebelah timur dengan Desa Dungkul, sebelah selatan dengan Desa Meteseh dan sebelah barat berbatasah dengan Desa Dempet. Adapun SMAN 1 Dempet berdekatan degan J1. Raya Demak-Godong, jarak SMAN 1 Dempet dengan Kecamatan Dempet sekitar $1 \mathrm{Km}$, sedangkan dengan Kabupaten Demak sekitar $10 \mathrm{Km}$ dan jarak dengan kota Semarang, ibu kota Provinsi sekitar $60 \mathrm{Km}^{9}{ }^{9}$

\section{Strategi dan Pendekatan Implementasi Penilaian Otentik Bidang Studi PAI dan Budi Pekerti di SMAN 1 Dempet}

Berdasarkan penelitian yang sudah peneliti lakukan di SMAN 1 Dempet sejak pertengahan Januari sampai akhir Febuari 2017 dan peneliti berpartisipasi secara langsung dilapangan untuk mengetahui bagaimana strategi dan pendekatan GPAI dalam implementasi penilaian otentik.Terkait dengan perencanaan pembelajaran PAI dan Budi Pekerti di SMAN 1 Dempet, peneliti telah mengamati secara langsung dengan adanya rencana pelaksanaan pembelajaran (RPP). Karena perencanaan merupakan suatu proses awal yang sangat penting dan menentukan langkah atau menentukan proses pembelajaran selanjutnya. Hal ini dibuktikan

\footnotetext{
${ }^{9}$ Wawancara dengan Ibu Luluk Istiqomah pada hari Senin 20 April 2017 dan studi dokumentasi SMAN 1 Dempet.
} 
oleh GPAI sebelum mengajar, sudah menyiapkan atau menyusun RPP tentang tatacara pengurusan jenazah terlebih dahulu.

Dengan adanya penyusunan rencana pelaksanaan pembelajaran atau RPP maka guru dapat merumuskan secara terstruktur dan sistematis untuk memudahkan proses pembelajaran itu sendiri. Selain dengan perencanaan tersebut guru seharusnya mendalami materi pelajaran yang akan disampaikan, hal ini bertujuan agar materi yang disampaikan tidak melebar dan hanya fokus pada materi yang disampaikannya. Dengan adanya perencanaan ini diharapkan pembelajaran yang dirumuskan tersebut dapat membawa perubahan pengetahuan peserta didik. Karena dalam pembelajaran pendidikan Agama Islam, peserta didik tidak hanya dituntut untuk menguasai materi pembelajaran saja tetapi peserta didik harus bisa memahami dan mengamalkannya dalam kehidupan sehari-hari sesuai dengan ajaran Islam. Dalam perencanaan penilaian otentik di SMAN 1 Dempet, kepala sekolah dan guru telah melakukannya, hal tersebut seperti diungkapkan Bapak Purnomo sebagai berikut:

"Mengenai penerapan penilaian otentik SMA kami telah melakukan perencanaan melalui suatu workshop dan tugas mandiri kepada guru-guru kami. Kemudian sudah dilaksanakan melalui kegiatan pembelajaran, penerapan penilaian otentik pada bidang studi Pendidikan Agama Islam sudah bagus". ${ }^{10}$

Berdasarkan hasil observasi dan dokumentasi, peneliti menemukan data tentang standar penilaian otentik di dalam dokumen evaluasi diri yang telah dilakukan

\footnotetext{
${ }^{10}$ Wawancara dengan bapak Purnomo selaku Kepala Sekolah SMAN 1 Dempet pada 15 Februari 2017.
}

kepala sekolah dan guru SMAN 1 Dempet. Berdasarkan data temuan tersebut, guru dalam perencanaan penilaian otentik bidang studi PAI dan Budi Pekerti dapat dideskripsikan sebagai berikut: ${ }^{11}$

1. Guru telah menyusun program tahunan (prota).

2. Guru telah menyusun program semesteran (promes).

3. Guru telah menyusun silabus.

4. Guru telah menyusun rencana pelaksanaan pembelajaran (RPP).

5. Guru telah menyusun kriteria ketuntasan (KKM).

6. Guru telah menyusun kisi-kisi soal.

7. Guru telah menyusun instrumen tes.

8. Guru telah menyusun rubrik penilaian.

9. Guru telah menyusun lembar observasi.

10. Guru telah menyusun lembar penilaian diri.

11. Guru telah menyusun lembar penilaian antar teman.

12. Guru telah menyusun lembar jurnal penilaian.

\section{Langkah-Langkah Strategi dan} Pendekatan dalam Penilaian Otentik Bidang Studi PAI dan Budi Pekerti

Terkait dengan pelaksanaan pembelajaran PAI dan Budi Pekerti di SMAN 1 Dempet ini peneliti sudah mengamati secara langsung di kelas, dan dalam pelaksanaan pembelajaran yang menggunakan penilaian otentik ini menjadikan sebuah acuan untuk mengetahui bagaimana respon peserta didik ketika proses belajar mengajar itu berlangsung.

Pada saat itu juga peneliti secara langsung ikut dalam proses pembelajaran,

${ }^{11}$ Observasi di SMAN 1 Dempet pada 15 Februari 2017. 
guru PAI dan Budi Pekerti menggunakan penilaian otentik. Tetapi dengan media seadanya penilaian otentik tetap efektif dan pembelajaran di kelas tidak menjadikan peserta didik tidak semangat belajar melainkan mereka masih tetap semangat belajar, walaupun dengan media pembelajaran seadanya.

Berdasarkan hasil wawancara peneliti dengan Bapak Ali Muksinguru Pendidikan Agama Islam dan Budi Pekerti menjelaskan bahwa "Ya, benar pak di SMA kami melaksanakan penilaian otentik, dari kelas $X$ sampai kelas XII". ${ }^{12}$ Pelaksanaan penilaian ini menunjukkan bahwa sekolah ini benar-benar sudah siap dengan segudang tugas penilaian.Harapannya ialah agar peserta didik bisa mendapatkan hasil yang maksimal.

Kemudian dari hasil pengamatan ketika Bapak Ali Muksin mengajar dan menerapkan penilaian proses di kelas XI menggunakan langkah-langkah pelaksanaan penilaian otentik, sebagai berikut: ${ }^{13}$

a. Setelah guru membuka pelajaran, beliau memasang sebuah media belajar (LCD).

b. Guru mengajak peserta didik mengamati video atau media belajaran yang ditampilkan.

c. Guru meminta peserta didik memberikan tanggapan dari isi video atau media belajar.

d. Ketika peserta didik mengkomunikasikan hasil analisa dari media pembelajaran guru mulai melaksanakan penilaian pengamatan terhadap hasil analisa yang disampaikan peserta didik.

\footnotetext{
${ }^{12}$ Wawancara dengan Ali Muksin sebagai Guru Pendidikan Agama Islam pada18 Februari 2017.

${ }^{13}$ Wawancara dengan Ali Muksin sebagai Guru Pendidikan Agama Islam pada18 Februari 2017.
}

e. Guru memberikan chek clist pada rubrik penilaian pengamatan yang telah disiapkan untuk menilai setiap indikator yang telah dikuasai masing-masing.

f. Setelah selesai memberikan daftar cek, guru menyampaikan umpan balik terhadap kekurangan dan kelebihan kemampuan peserta didik.

g. Sedangkan dalam pelaksanaan penilaian pengetahuan, dilaksanakan pada akhir pembelajaran dijadikan fungsi sebagai penilaian formatif setiap KD. Teknik yang digunakan adalah melalui tes dan penugasan.

h. Adapun dalam penilaian ketrampilan, teknik yang digunakan adalah memberikan tugas proyek. Misalnya dalam bidang studi PAI dan Budi Pekerti, mempraktikkan tatacara pengurusan jenazah".

Hal di atas didukung denganfakta mengenai guru yang melaksanakan penilaian otentik bidang studi PAI dan Budi Pekerti dapat dijelaskan sebagai berikut: ${ }^{14}$

1. Guru dalam menilai aspek sikap spiritual (KI-1) dan aspek sikap (KI-2) menggunakan beberapa teknik penilaian diantaranya:

a. Teknik observasi disertai pedoman penilaian observasi, rubrik penilaian observasi, skala penilaian observasi, dan penskoran penilaian observasi. Dari data menunjukkan sikap spiritual dengan tema diskusi "memaknai pengurusan jenazah". Khoirun Nisa' mampu mencapai skor nilai sebanyak 13 berbanding skor

\footnotetext{
${ }^{14}$ Observasi dan Dokumentasi di SMAN 1 Dempet pada 19 Februari 2017.
} 
maksimal 15. Artinya dia mampu mencapai nilai kuantitatif sebesar 83 . Hal ini khoirun Nisa' memperoleh peringkat baik (B) dalam peringkat nilai kualitatif. Pelaksanaan penilaian dengan teknik observasi ini.

b. Teknik penilaian diri disertai lembar instrumen penilaian diri, pedoman penilaian diri, lembar penskoran penilaian diri. Dari data menunjukkan sikap sosial, menunjukkan perilaku kekeluargaan. Mampu mencapai skor nilai sebanyak 10 berbanding skor maksimal 11 ini artinya dia mampu mencapai nilai kuantitatif sebesar 90 . Hal ini dapat dikatakan bahwa Khoirun Nisa' mendapat peringkat sangat baik (A) dalam peringkat nilai kualitatif.

c. Teknik penilaian antar teman disertai dengan lembar penilaian antar teman, rubrik penilaian antar teman, dan lembar pedoman penskoran. Dari data menunjukkan sikap perilaku jujur terhadap pengurusan jenazah. Ketika Khoirun Nisa' dinilai oleh temannya yang bernama Siti Mariyam, terhadap kemampuan pengurusan jenazah dia memberi skor 9 dibanding skor maksimal 10. Ini artinya dia mampu bersikap jujur dan tanggung jawab kepada teman, sehingga menilai kemampuan pengetahuan atau praktik pengurusan jenazah secara kuantitatif sebesar 90 . Hal ini Khoirun Nisa' mendapatkan peringkat sangat baik (A) dalam peringkat nilai kualitatif. d. Teknik penilaian jurnal disertai dengan lembar rubrik penilaian jurnal, pedoman penilaian jurnal dan petunjuk perskor. Dalam pelaksanaan penilaian jurnal ini seperti data tentang sikap spiritual yang ditemukan dari peserta didik bernama Mita Aulia. Karena dia selalu berdoa sebelum dan sesudah melakukan pekerjaan, selalu mengucapkan salam sesudah dan sebelum menyampaikan pendapat, dan selalu merasakan keberadaan dan kebesaran Allah. Maka nilai kuantitatif yang dicapai Mita sebesar 19 berbanding skor maksimal 20, sehingga ia mencapai nilai sikap spiritual dan jurnal sebesar 95 dan nilai peringkat kualitatif sangat baik (A).

Guru dalam melaksanakan penilaian aspek pengetahuan (KI-3) dengan menggunakan teknik penilaian tes dan non tes, yaitu:

a. Teknik tes memakai jenis tes tulis diantaranya (a). Bentuk tes pilihan ganda (PG), (b). Bentuk tes isian singkat. Sedangkan jenis tes subyektif yang digunakan diantaranya: (a). Bentuk tes lisan, dan (b). Bentuk tes uraian singkat.

b. Teknik non tes menggunakan dua jenis, yaitu: (a). Tugas mandiri, dan (b). Tugas kelompok.

2. Guru melaksanakan penilaian aspek ketrampilan (KI-4) menggunakan.

a. Teknik penilaian kinerja disertai lembar pedoman penilaian kinerja, instrumen penilaian kinerja dan pedoman penskoran, serta lembar daftar cek (check clist). Dalam 
pelaksanaan penilaian kinerja peserta didik kelas XI menunjukan data hasil nilai rerata kuantitatif sebesar 93, dan ini mencapai peringkat nilai kualitatif sangat baik (A) (Data terlampir)

b. Guru dalam melaksanakan teknik penilaian produk menggunakan lembar penilaian produk dan skala penilaian. Dari pelaksanaan penilaian produk menunjukkan nilai rerata kuantitatif sebesar 85 sama artinya dengan peringkat nilai rerata kualitatif dalam predikat baik (B). (Data terlampir).

c. Guru dalam melaksanakan teknik penilaian proyek, disertasi lembar pedoman daftar cek penilaian proyek dari rubrik perskoran penilaian proyek. Dalam pelaksanaan penilaian proyek data yang ditunjukkan dari nilai $\mathrm{M}$. Maulana Zakaria. Memperoleh skor sebanyak 23 berbanding skor maksimal 27, sehingga dia memperoleh nilai rerata kuantitatif 85 sama artinya mencapai rerata nilai kualitatif dalam predikat baik (B), demikian pula rerata kelas sebesar 85 . Hal ini sama artinya nilai rerata kelas secara kualitatif dalam predikat baik (B). (Data terlampir).

d. Guru dalam melaksanakan teknik penilaian pertofolio, disertai lembar pedoman skala penskoran, dan penilaian. Dalam pelaksanaan penilaian portofolio, data hasil penilaian portofolio yang berhasil dikumpulkan oleh Khoirun Nisa', sebanyak tiga kali penilaian yaitu:
80, 86, dan 86 memperoleh nilai rerata sebesar 84 secara kuantitatif dan rerata nilai kualitatif sebesar 78 dan secara kualitatif dengan predikat sedang (S).

\section{Analisis Strategi dan Pendekatan} Guru PAI dalam Implementasi Penilaian Otentik Bidang Studi PAI dan Budi Pekerti di SMAN 1 Dempet

Memilih Strategi dan Menetapkan Pendekatan dalam Penilaian Otentik Bidang Studi PAI dan Budi Pekerti di SMAN 1 Dempet.

Kegiatan pembelajaran dan penilaian pembelajaran kedua-duanya saling terkait dan tidak terpisahkan.Esensi penilaian pembelajaran bertujuan untuk mengukur keberhasilan peserta didik dalam penguasaan kompetensi yang telah ditentukan serta untuk bahan evaluasi guru terhadap kualitas pembelajaran yang telah dilakukan. Di samping itu, penilaian hasil pembelajaran juga bertujuan menilai efektivitas, kegiatan pengajaran sebagai bahan untuk perbaikan dan penyempurnaan program serta pelaksanaannya.

Pelaksanaan hasil belajar ini tidak akan dapat berjalan dengan baik, tanpa melibatkan guru. Sebab tugas utama guru adalah mendidik, mengajar, membimbing, mengarahkan, melatih, menilai dan mengevaluasi peserta didik. Untuk dapat melaksanakan tugas utama itu, guru harus memiliki penguasaan cara menilai dan mengevaluasi,yaitu, harus memahami secara jelas tujuan yang ingin dicapai, aspek apa saja yang akan dinilai, fokus penilaian yang akan dilakukan dan jenis atau bentuk penilaian apa yang tepat digunakan atau menilai apa saja yang harus dinilai dari 
peserta didik secara langsung dan secara alamiah.

Di dalam penilaian otentik hendaknya dapat menilai dari kesiapan peserta didik serta proses dan hasil belajar secara utuh. Kesiapan guru dalam mempersiapkan segala perangkat pembelajaran dan penilaian secara utuh dan lengkap. Berdasarkan hasil penelitian, seperti yang telah penulis kemukakan di atas yang berkenaan dengan guru dalam perencanaan penilaian otentik dapat dibahas sebagai berikut :

1. Guru sudah terbukti menyusun dokumen program tahunan (Prota), bidang studi PAI dan Budi Pekerti kelas XI sendiri dengan mengembangkan standar isi (SI) yang ada dalam standar kelulusan minimal (SKL). Komponen yang dalam program tahunan tersebut sudah mencakup KI-1 sampai dengan KI-4 kompetensi dasar (KD), dan telah menentapkan alokasi waktu dalam setiap kompetensi.

2. Guru sudah terbukti mampu menyusun dukumen program semester (Promes) bidang studi PAI dan Budi Pekerti yang mencakup KI-1 samapai dengan KI-4, kompetensi dasar (KD). Pengembangan alokasi waktu untuk setiap jam tatap muka dalam seminggu dalam sebulan, serta sudah melakukan perencanaan penilaian yang berbentuk ulangan harian, UTS, dan UAS yang akan dilaksanakan tiap semester dalam satu tahun pelajaran.

3. Guru sudah terbukti mampu menyusun silabus sendiri bidang studi PAI dan Budi Pekerti kelas XI yang mencakup KI-1 sampai dengan KI-4, mengembangkan kompetensi dasar (KD) kedalam indikator, sesuai materi pokok pembelajaran yang akan dilaksanakan dalam setiap kegiatan pembelajaran yang dipadukan dengan teknik penilaian yang akan dilaksanakan yang terdiri dari :

a. Perencanaan penilaian untuk aspek sikap spiritual (KI-1) direncanakan dengan jenis dan teknik observasi, penilaian diri, penilaian antar teman,dan penilaian jurnal.

b. Penilaian untuk aspek sikap sosial (KI2), telah direncanakan dengan jenis dan teknik observasi, penilaian diri, penilaian antar teman, dan penilaian jurnal.

c. Perencanaan penilaian untuk aspek pengetahuan (KI-3), telah mencakup teknik penilaian jenis tes tulis, tes lisan, dan penugasan.

d. Perencanaan penilaian untuk aspek keterampilan (KI-4), telah direncanakan dengan penggunaan jenis dan teknik penilaian kinerja, dan portofolio.

4. Guru sudah terbukti mampu menyusun rencana pelaksanaan pembelajaran (RPP), bidang studi PAI dan Budi Pekerti kelas XI sendiri yang mencakup KI-1 sampai dengan KI-4. Sudah Mengembangkan kompetensi dasar (KD) kedalam indikator pembelajaran dan memadukan dengan tujuan pembelajaran yang akan dicapai bersamaan dengan materi pokok dan metode pembelajaran. model pembelajaran, serta dilengkapi dengan langkah-langkah pembelajaran yang mencakup alokasi waktu, perencanaan media pembelajaran yang akan digunakan dan sumber pembelajaran yang dijadikan acuan. Kisikisi penilaian juga sudah dibuat yang mencakup indikator pencapaian kompetensi, aspek-aspek ranah penilaian 
yang akan diukur, teknik penilaian serta disebutkan contoh instrumen tes dan masih dilengkapi dengan lembar penilaian, rubrik penilaian, pedoman penskoran, kisi-kisi soal, instrumen soal tes baik aspek sikap sepiritual (KI-1) dan aspek sikap sosial, (KI-2), pengetahuan (KI-3), dan keterampilan (KI-4).

5. Guru sudah terbukti mampu menyusun kriteria ketuntasan belajar (KKM) bidang studi PAI dan Budi Pekerti, dengan berpedoman kepada kriteria pencapaian ketuntasan, dengan mempertimbangkan tinggi, sedang, dan rendahnya aspek kompleksitas, dayadukung, dalam setiap KDdengan batasan nilai kuantitatif pada masing-masing kompetensi dasar (KD) untuk tiap semester dan dalam satu tahun pelajaran.

6. Guru sudah terbukti mampu menyusun kisi -kisi soal, bidang studi PAI dan Budi Pekerti kelas XI yang mencakup penilaian aspek sikap spiritual (KI-1), penilaian aspek sikap sosial (KI-2).

7. Bahwa guru kelas XI sudah menyusun rubrik penilaian mencakup penilaian aspek sikap spiritual (KI-1) sikap sosial spiritual (KI-2). Sudah sesuai pengetahuan (KI-3). dan aspek keterampilan (KI-4). Sudah sesuai permendikbud NO. 66 Tahun 2013 tentang Standar Pernilaian Pendidikan yang dijadikan acuan penilaian otentik.

8. Bahwa guru kelas XI dalam menyusun lembar observasi sudah mencakup penilaian sikap, aspek spiritual (KI-1), sikap sosial (KI-2), aspek pengetahuan (KI-3), dan aspek keterampilan.

9. Bahwa guru kelas XI dalam menyusun lembar penilaian diri mencakup penilaian aspek sikap spiritual (KI-1), sikap sosial
(KI-2), aspek pengetahuan (KI-3), dan aspek keterampilan (KI-4).

10. Bahwa guru kelas XI dalam menyusun lembar penilaian antar teman mencakup penilaian aspek sikap spiritual (KI-1), sikap sosial (KI-2), aspek pengetahuan, (KI-3), dan aspek keterampilan (KI-4).

11. Bahwa guru kelas XI dalam menyusun lembar jurnal penilaian mencakup penilaian aspek sikap spiritual (KI-1), sikap sosial (KI-2), aspek pengetahuan (KI-3), dan aspek keterampilan (KI-4). Sudah sesuai permendikbud NO. 66 Tahun 2013 tentang Standar Penilaian Pendidikan.

\section{Langkah-Langkah Strategi dan Pendekatan dalam Penilaian Otentik Bidang Studi PAI dan Budi Pekerti di SMAN 1 Dempet}

Pelaksanaan strategi dan pendekatan dalam penilaian otentik bidang studi PAI dan Budi Pekerti tidak dapat terlepas dari proses pembelajaran otentik. Dalam pelaksanaan otentik ini, setiap teknik penilaian yang digunakan dalam mengukur kemampuan peserta didik juga mengacu pada pendekatan saintifik yaitu: mengamati, menanya, mencoba, menalar, dan mengkomunikasikan. Sebab pendekatan saintifik mencerminkan kemampuan ketiga ranah kompetensi. Ketiga ranah tersebut dapat dilihat dari keaktifan, keberanian, kreativitas. Dalam upaya melaksanakan pelaksanaan penilaian otentik bidang studi PAI dan Budi Pekerti SMAN 1 DEMPET.

Selanjutnya guru dalam melakuakan penilaian otentik bidang studi PAI dan Budi dapat dibahas sebagai berikut:

1. Bahwa guru kelas XI sudah terbukti mampu melaksanakan penilaian pada 
aspek sikap spiritual (KI-1) dan aspek sikap sosial (KI-2) peserta didik dengan menggunakan teknik sebagai berikut:

a. Dalam menggunakan teknik observasi pertama kali guru menggunakan instrumen tes, berupa lembar pedoman 'penilaian observasi dengan memberikan tanda cek, tanda daftar atau rubrik check list observasi dengan memperhatikan petunjuk pelaksanaannya yang berada dalam pedoman penilaian.

b. Dalam melaksanakan teknik penilaian diri, langkah yang di lakukan guru adalah dengan menggunakan lembar instrumen penilaian diri, disertai pedoman penilaian, serta penskoran penilaian diri. Pelaksanaan penilaian diri bertujuan untuk mengukur sikap perilaku. Langkah guru adalah dengan meminta kepada salah satu peserta didik untuk menghafalkan tata cara pengurusan jenazah di depan kelas secara bergantian. Sesudah peserta didik selesai menghafal, guru kemudian memberikan lembar penilaian diri kepada peserta didik bersangkutan dan memintanya untuk memberikan tanda cek.

c. Dalam melaksanakan teknik penilaian antar teman, langkah yang dilakukan guru adalah membagikan lembar penilaian antarteman yang disertai rubrik penilaiannya, dan lembar pedoman penskoranya kepada salah seorang peserta didik. Penilaian antarteman bertujuan untuk menilai perilaku jujur, tanggung jawab, kedisiplinan peserta didik terhadap sikap yang dimiliki teman sejawatnya.
Langkah yang dilakukan guru adalah pada waktu salah seorang peserta didik maju kedepan kelas menghafalkan tatacara pengurusan jenazah. Maka guru kemudiaan memberikan lembar penilaian kepada seorang peserta didik lain dan memintanya menilai dengan cara memberikan tanda cek $(\sqrt{ })$ pada kolom kemampuan. Penilaian ini dilakukan untuk mengetahui kemampuan hafalan pengurusan jenazah sesuai keadaan sesungguh nya. Setelah dia selesai menilai temannya, guru meminta lembar penilaian tersebut. Terbukti dengan penilaian antarteman ini, memberikan dampak baik dalam meningkatkan sikap perilaku jujur, bertanggung jawab dan disiplin peserta didik terhadap sikap temannya.

d. Dalam melaksanakan tehnik penilaian jurnal, pertama yang dilakukan guru adalah menggunakan lembar rubrik penilaian jurnal yang disertai pedoman penilaian jurnal, dan petunjuk penskorannya. Penilaian jurnal adalah catatan guru yang dilakukan untuk mengukur kekuatan dan kelemahan sikap dan perilaku peserta didik. Misalnya ketika para peserta didik sedang melakukan kegiatan salat berjamaah, apakah mereka melakukan dengan penuh khusu' atau banyak bergerak. Maka guru dapat memberikan tanda cek $(\sqrt{ })$ pada tingkatan sikap baik sekali (BS), atau baik (B), atau cukup (C), dan atau kurang (K) sesuai kolom kriteria sikap spiritual atau sikap sosial peserta didik. Dengan penilaian jurnal menunjukan bukti nilai kekuatan sikap perilaku rajin beribadah. 
2. Bahwa guru kelas XI terbukti dalam melaksanakan penilaian, aspek pengetahuan (KI-3) meggunakan dua teknik tes, yaitu: penilaian tes objektif dan tes subjektif.

a. Dalam melaksanakan jenis tes objektif, tes yang digunakan guru berupa tes tulis. Bentuk tes pilihan ganda (PG), isian, menjodohkan, benar salah (B-S). Instrumen butir soalnya dibuat guru sendiri, dan digunakan untuk ulangan formatif, dengan berpedoman pada kisi-kisi soal yang dibuat sebelumnya . Lengkap dengan kunci jawaban, dan pedoman penskoran. Adapun instrumen soal tes UTS dan UAS dibuat oleh tim pembuat soal MGMP Kabupaten Demak. Semua instrumen yang disertai kisi-kisi soal, walaupun tampak sederhana tetapi sudah terukur karena sudah sesuai dengan indikator yang akan dicapai dalam setiap KD yang diajarkan kepada peserta didik. Terbukti hasil tes bentuk objektif.

1) Bentuk tes isian singkat, terbukti telah dilaksanakan guru disertai dengan menggunakan instrumen tes, kisi-kisi soal, kunci jawaban, dan pedoman penskoran penilaian.

2) Bentuk tes benar salah (B-S), telah dilakukan guru disertai dengan menggunakan instrumen tes, kisikisi soal, kunci jawaban, dan pedoman penskoran penilaian.

3) Bentuk tes menjodohkan terbukti telah dilaksanakan guru dengan menggunakan instrumen tes yang disertai pembuatan kisi-kisi soal, kunci jawaban, dan pedoman penskoran penilaian.

b. Tes subjektif menggunakan bentuk tes lisan, telah dilaksanakan guru berbentuk tes uraian singkat. Pelaksanaan tes uraian singkat terbukti telah dilaksanakan guru dengan menggunakan instrumen tes dilengkapi dengan pembuatan kisi-kisi soal, kunci jawaban, dan pedoman penskoran penilaian.

c. Teknik non tes juga terbukti telah dilaksanakan dengan menggunakan dua jenis yaitu : berupa tugas mandiri, dan tugas kelompok. kedua jenis penilaian non tes ini dilakukan guru untuk memberikan pengayaan materi pelajaran. Pelaksanaan tugas mandiri dan tugas kelompok memanfaatkan pada jenis tugas yang telah tersedia dalam buku lembar tugas yang sudah dimiliki oleh peserta didik.

d. Guru telah melaksanakan penilaian aspek keterampilan (KI-4). Teknik penilaian aspek keterampilan (KI-4) diantaranya:

1. Teknik penilaian kinerja, guru telah melaksanakan dengan menggunakan lembar pedoman penilaian kinerja, disertai penggunaan instrumen penilaian kinerja, pedoman penskoran, dan lembar daftar cek $(\sqrt{ })$. Penilaian kinerja terbukti membawa dampak pada skil keterampilan peserta didik dalam proses membuat sebuah karya tertentu. Penilaian kinerja juga menunjukkan nilai kuantitatif rata-rata 80 dan pada peringkat nilai kualitatif baik (B). 
2. Teknik penilaian produk, guru telah melaksanakan dengan menggunakan lembar penilaian produk disertai skala penilaiannya. Penilaian kinerja terbukti membawa dampak pada skill keterampilan peserta didik dalam menghasilkan sebuah produk tertentu. Penilaian produk juga menunjukkan nilai kuantitatif ratarata 80 dan pada peringkat nilai kualitatif baik (B).

3. Teknik penilaian portofolio, bahwa guru telah melaksanakan dengan menggunakan lembar pedoman penilaian portofolio dan pedoman skala penskoran. Teknik penilaian merupakan kumpulan nilai dari produk karya peserta didik yang dipajang pada papan pajangan disertai tanggal penilaian dan nilai kuantitasnya.

Dengan kata lain, pelaksanaan hasil penilaian otentik bidang studi PAI dan Budi Pekerti dapat dilaporkan sebagai berikut:

1. Penggunaan penilaian teknik observasi yang disertai pedoman penilaian observasi, daftar check list, petunjuk penilaian dan pedoman penilaian sangat efektif digunakan untuk menilai sikap spiritual (KI-1) dan aspek sikap sosial (KI-2), karena menggunakan alat penilaian yang jelas, dapat terukur dan sudah sesuai Permendibud NO. 66 Tahun 2013 tentang Standar Penilaian Pendidikan, yang dijadikan sebagai bahan acuan penilaian.

2. Penggunaan teknik penilaian diri yang disertai dengan lembar instrumen penilaian, pedoman penilaian, dan penskoran sangat efektif untuk menilai sikap kejujuran, tanggungjawab peserta didik dalam suatu kemampuan sikap spiritual (KI-1) dan sikap sosial (KI-2).

3. Penggunaan teknik penilaian antarteman yang disertai dengan lembar instrumen penilaian, pedoman penilaian, dan penskoran sangat efektif untuk menilai sikap kejujuran, tanggungjawab, dan kedisiplinan peserta didik.

4. Penggunaan teknik penilaian jurnal yang disertai dengan lembar rubrik penilaian jurnal, pedoman penilaian jurnal, dan petunjuk. Secara efektif untuk menilai kekuatan dan kelemahan sikap spiritual (KI-1) dan sikap sosial (KI-2) peserta didik karena menggunakan alat penilaian yang jelas, dapat terukur, dan sudah sesuai Permendikbud NO. 66 Tahun 2013 tentang Standar Penilaian Pendidik yang dijadikan acuan penilaian.

5. Penggunaan tes objektif dan tes berupa tes pilihan ganda (PG), isian singkat, menjodohkan, benar salah (BS), dan tes subjektif berupa tes lisan dan jawaban singkat serta penegasan berbentuk tugas mandiri dan kelompok sangat efektif untuk menilai kemampuan aspek pengetahuan (KI-3).

6. Penggunaan teknik penilaian kinerja, penilaian produk, dan penilaian portofolio yang disertai lembar pedoman penilaian instrumen penilaian, pedoman penskoran, dan lembar daftar $\operatorname{cek}(\sqrt{ })$. Hal ini sangat efektif untuk menilai aspek keterampilan (KI-4), karena menggunakan alat penilaian yang jelas, dapat terukur, dan sudah sesuai Permendikbud NO. 66 Tahun 2013 tentang Standar Penilaian Pendidikan yang dijadikan acuan penilaian. 


\section{KESIMPULAN}

Pemilihan strategi dan penetapan pendekatan dalam penilaian otentik bidang studi PAI dan Budi Pekerti di SMAN 1 Dempet telah berjalan baik sesuai dengan prosedur. Hal ini dibuktikan guru telah membuat secara lengkap dokumen seperti (prota), (promes), silabus, (RPP), (KKM), kisi-kis soal, instrumen soal, rubrik penilaian, lembar observasi, lembar penilaian diri, lembar penilaian antarteman, dan jurnal sudah sesuai. Agar strategi dan pendekatan dalam penilaian otentik bidang studi PAI dan Budi Pekerti dapat terlaksana dengan baik dan dapat mengukur kompetensi peserta didik secara alami, baik aspek sikap, pengetahuan, dan keterampilannya, maka perlu adanya kesiapan guru dalam merancang penilaian, kemampuan guru dalam melaksanakan penilaian, dan mengolah nilai hasil pembelajaran harus bekerja sama dengan antarteman, kepala SMA, pengawas SMA, orang tua peserta didik dalam memikirkan dan membantu ketersediaan sarana pendukung dan dana pendamping guna suksesnya implementasi penilaian otentik di SMAN 1 Dempet

Langkah-langkah strategi dan pendekatan dalam penilaian otentik bidang studi PAI dan Budi Pekerti di SMAN 1 Dempet telah berjalan dengan efektif. Hal ini dibuktikan guru dalam proses pembelajaran telah menggunakan strategi dan pendekatan yang relevan dan guru telah menilai bedasarkan aspek sikap spiritual (KI-1), dan sikap sosiak (KI-2 aspek pengetahuan (KI-3), aspek keterampilan (KI-4).

\section{DAFTAR PUSTAKA}

Arikunto, Suharsimi, Prosedur Penelitian Suatu Pendekatan Praktik, Jakarta: Rineka Cipta, 2006.

Dacholfany, M. Ihsan., Inisiasi Strategi Manajemen Lembaga Pendidikan Islam Dalam Meningkatkan Mutu Sumber Daya Manusia Islami di Indonesia Dalam Menghadapi Era Globalisasi, Jurnal At-Tajdid, Volume. 1, No. 1 Januari-Juni 2017.

Ghony, Djunaidi., Metodologi Penelitian Kualitatif, Jogjakarta: Arruz Media, 2012.

Hadi, Sutrisno,Metodologi Reseach 3, Yogyakarta: Yayasan Penerbit Fakultas Psikologi UGM, 1990.

Indrianto, Nur., dan Bambang Supomo, Metodologi Penelitian Bisnis Untuk Akuntansi Manajemen, Yogyakarta: BPFF, 1999.

Kunandar, Penilaian Outentik (Penilaian Hasil Belajar Peserta Didik Bedasarkan Kurikulum 2013) Satu Pendekatan Praktis, Disertai dengan Contoh, Jakarta: PT.Raja Grafindo Persada, 2014.

Kurniasih, Imas \& Berlin Sani., Implementasi Kurikulum 2013 Konsep \& Penerapan, Surabaya: Kata Pena, 2014.

Majid, Abdul., Penilaian Autentik Proses dan Desain Belajar, Bandung: PT. Remaja Rosdakarya, 2015.

Marison,Metode Penelitian Survei, Jakarta: Prenada Media Grup, 2012.

Nazir, Moh,Metode Penelitian, Surabaya: Ghalia Indonesia, 1988.

Subagyo, P. Joko,Metode Penelitian Dalam

Teori Dan Praktek, Jakarta: Rineka Cipta, 2004. 